\title{
Game Analysis of the Rent Seeking Model of Scientific Research Activity Based on Bounded Rationality
}

\author{
Ying $\mathrm{Li}^{1, \mathrm{a}}$, Xiang $\mathrm{Xie}^{1, \mathrm{~b}}$ and Xiaohui $\mathrm{Hou}^{2, \mathrm{c}}$ \\ ${ }^{1}$ School of Economics and Management, Beijing Jiaotong University, Beijing 100044, China; \\ ${ }^{2}$ Office of research, Beijing Jiaotong University, Beijing 100044, China. \\ aliyingotw@163.com, ’xxie@bjtu.edu.cn, ${ }^{\mathrm{c} x h h o u @ ~ b j t u . e d u . c n ~}$
}

Keywords: rent seeking; bounded rationality; evolutionary game; scientific research.

\begin{abstract}
The research field exists the phenomenon of rent-seeking widely, through the establishment of the three party model, analysis under different conditions of scientific research project application and research project approval returns, pointed out that the change of both sides' rent-seeking strategies under different conditions. The game analysis of this paper is to establish the two sides of the game is only based on bounded rationality, avoid most scholars analyzed the game when the game of both sides has required harsh conditions of complete rationality, game analysis and conclusion are more general. In this paper, based on the analysis of evolutionary game theory, the paper puts forward some concrete suggestions on reducing rent seeking behavior.
\end{abstract}

\section{Introduction}

Scientific research includes a series of processes. A great amount information asymmetry exist in the process of application, implementation and acceptance of research project. Information asymmetry will lead to rent seeking in the review process of research project, then result in the inefficient distribution of research resource and waste of national resource. Game analysis of the rent-seeking model which provides theoretical guidance for precaution and overcome of the rentseeking in scientific research is very important. Most scholars analyzed the game of rent-seeking model on the basis of complete rationality, actually, the rationality of person expresses in complex decision problem couldn't meet the demand of this complete rationality. ${ }^{[1]}$ This paper analyzes the rent-seeking model of scientific research based on the bounded rational evolutionary game, and the game player could adjust their strategies constantly to reach dynamic equilibrium finally. Therefore, to analyze the rent-seeking model by game analysis is very applicable. ${ }^{[2]}$

\section{Rent-seeking model building}

The main target of this paper is the rent-seeking behavior in the application stage of university scientific research. In this stage, the participants of rent-seeking are approval unit, application unit and supervision department. The specific model is assumed as follows:

(1) Suppose the supervision department didn't seek rent from the application unit and approval unit, the approval unit and application unit could select two strategies: seek rent or not.

(2) Suppose the project cost of a research is V; actual project fund is Y; the bribe amount is R; the inspection cost of supervision department is $C$; the probability of successful inspection of rent seeking is $p$, the probability of failure is (1-p). If the inspect succeeded, the approval unit and application unit would be punished, and the penalties of them are $\mathrm{KR}$ and $\mathrm{L}(\mathrm{Y}-\mathrm{V})$ respectively; in general case, $\mathrm{Y}-\mathrm{V}-\mathrm{R}>0$

(3) In view of above-mentioned assumption, the payoff matrix of approval unit, application unit and supervision department shown as Table 1. 
Table 1 The payoff matrix

\begin{tabular}{ccccc}
\hline & & \multicolumn{2}{c}{ Inspect } & \multirow{2}{*}{ not inspect } \\
\cline { 3 - 4 } & & Successful (P) & Failure 1-P $)$ & \\
\hline \multirow{3}{*}{ Rent-seeking } & approval unit & $-(\mathrm{K}-1) \mathrm{R}$ & $\mathrm{R}$ & $\mathrm{R}$ \\
& application unit & $-(\mathrm{L}-1)(\mathrm{Y}-\mathrm{V})-\mathrm{R}$ & $\mathrm{Y}-\mathrm{V}-\mathrm{R}$ & $\mathrm{Y}-\mathrm{V}-\mathrm{R}$ \\
& supervision department & $\mathrm{KR}+\mathrm{L}(\mathrm{Y}-\mathrm{V})-\mathrm{C}$ & $-(\mathrm{Y}-\mathrm{V})-\mathrm{C}$ & $-(\mathrm{Y}-\mathrm{V})$ \\
\multirow{5}{*}{ Not rent-seeking } & 0 & 0 & 0 \\
& approval unit & 0 & 0 & 0 \\
& application unit & $-\mathrm{C}$ & $-\mathrm{C}$ & 0 \\
\hline
\end{tabular}

\section{Evolutionary game analysis of rent-seeking model}

Suppose the probability of government supervision department to do inspection is $\mathrm{x}$; and the opposite probability is 1-x; the probability of rent-seeking of application unit is $y$, and the opposite probability is 1-y; based on Table1, we can get the income matrix as follow (Table 2).

Table 2 The income matrix

\begin{tabular}{ccc}
\hline & Not inspect(1-x) & Inspect $(\mathrm{x})$ \\
\hline Rent-seeking (y) & $(\mathrm{Y}-\mathrm{V}-\mathrm{R}),-(\mathrm{Y}-\mathrm{V})$ & {$[-(\mathrm{L}-1)(\mathrm{Y}-\mathrm{V})-\mathrm{R}] \mathrm{P}+[\mathrm{Y}-\mathrm{V}-\mathrm{R}](1-\mathrm{P}),[\mathrm{KR}+\mathrm{L}(\mathrm{Y}-\mathrm{V}-\mathrm{C})] \mathrm{P}+[-(\mathrm{Y}-\mathrm{V})-\mathrm{C}](1-\mathrm{P})$} \\
\hline Not rent-seeking (1-y) & 0,0 & $0,-\mathrm{C}$ \\
\hline
\end{tabular}

First, analysis of the application unit.

Based on Table 2, we can get that the expected income is $U_{s 1}$ if application unit seek rent from approval unit, otherwise, the expected income is $U_{s 2}$, and the average income is $U_{s}$. The dynamic equations $\mathrm{F}(\mathrm{y})$ of them are:

$$
\begin{aligned}
& U_{S 1}=(1-\mathrm{x}) *(\mathrm{Y}-\mathrm{V}-\mathrm{R})+\mathrm{x}\{[-(\mathrm{L}-1) *(\mathrm{Y}-\mathrm{V})-\mathrm{R}] \mathrm{P}+[\mathrm{Y}-\mathrm{V}-\mathrm{R}] *(1-\mathrm{P})\} \\
& \begin{aligned}
U_{S 2} & =(1-\mathrm{x}) * 0+\mathrm{x} * 0 \\
U_{S}= & \mathrm{y} * U_{S 1}+(1-\mathrm{y}) * U_{S 2}=\mathrm{y} *[(\mathrm{Y}-\mathrm{V})(1-\mathrm{yLP})-\mathrm{R}] \\
\mathrm{F}(\mathrm{y}) & =\mathrm{dy} / \mathrm{dt}=\mathrm{y} *(\mathrm{US} 1-\mathrm{US}) \\
& =\mathrm{y}\{\mathrm{US} 1-[\mathrm{y} * \mathrm{US} 1+(1-\mathrm{y}) \mathrm{US} 2]\} \\
& =\mathrm{y}(1-\mathrm{y})[(\mathrm{Y}-\mathrm{V})(1-\mathrm{xLP})-\mathrm{R}]
\end{aligned}
\end{aligned}
$$

Define $(1)=0$, then $y=0, y=1$, or $x=(Y-V R) /(Y-V) L P$

When $\mathrm{x}=(\mathrm{Y}-\mathrm{VR}) /(\mathrm{Y}-\mathrm{V}) \mathrm{LP}$, for all $\mathrm{y}$ that $\mathrm{F}(\mathrm{y})=0$, that all $\mathrm{y}$ is steady; If $\mathrm{x} \neq(\mathrm{Y}-\mathrm{V}-\mathrm{-R})(\mathrm{Y}-$ V)LP, evolutionary stable strategy should meet that $\mathrm{F}(\mathrm{y})=0$ and $F^{\prime}\left(y^{*}\right)<0$, when $\mathrm{x}>(\mathrm{Y}-\mathrm{VR}) /$ $(\mathrm{Y}-\mathrm{V}) \mathrm{LP}, F^{\prime}(0)<0$, therefore, $y^{*}=0$ is stable strategy ; when $\mathrm{x}>(\mathrm{Y}-\mathrm{VR}) /(\mathrm{Y}-\mathrm{V}) \mathrm{LP}, F^{\prime}(1)<0$, therefore, $y^{*}=0$ is stable strategy.

Second, analysis of the supervision department

If the supervision department selects inspection, the income is $U_{c 1}$, otherwise, the income is $U_{c 2}$, and the average income is $\mathrm{U}_{\mathrm{c}}$. The replicator dynamics equations $\mathrm{F}(\mathrm{y})$ are:

$$
\begin{aligned}
& U_{c 1}=\mathrm{y} *[\mathrm{KR}+\mathrm{L}(\mathrm{Y}-\mathrm{V}-\mathrm{C})] \mathrm{P}+[-(\mathrm{Y}-\mathrm{V})-\mathrm{C}](1-\mathrm{P})+(1-\mathrm{y}) *(-\mathrm{C}) \\
& \begin{aligned}
U_{c 2} & =\mathrm{y} *[-(\mathrm{Y}-\mathrm{V})]+(1-\mathrm{y}) * 0 \\
U_{c}= & \mathrm{x}^{*} \mathrm{U}_{\mathrm{c} 1}+(1-\mathrm{x})^{*} \mathrm{U}_{\mathrm{c} 2} \\
\mathrm{~F}(\mathrm{x}) & =\mathrm{dx} / \mathrm{dt}=\mathrm{x} *\left(\mathrm{Uc} 1 . \mathrm{U}_{\mathrm{c}}\right) \\
& =\mathrm{x}^{*}(1-\mathrm{x})^{*}\{\mathrm{Yp}[\mathrm{KR}+(\mathrm{Y}-\mathrm{V})(\mathrm{L}+1)]-\mathrm{C}\}
\end{aligned}
\end{aligned}
$$

Define $(2)=0$, then $\mathrm{x}=0, \mathrm{x}=1$, or $\mathrm{y}=\mathrm{c} / \mathrm{p}[\mathrm{Kr}+(\mathrm{Y}-\mathrm{V})(\mathrm{L}+1)]$ 
When $\mathrm{y}=\mathrm{c} / \mathrm{p}[\mathrm{Kr}+(\mathrm{Y}-\mathrm{V})(\mathrm{L}+1)]$, for all $\mathrm{x}, \mathrm{F}(\mathrm{x})=0$ that all $\mathrm{x}$ is steady; If $\mathrm{y} \neq \mathrm{c} / \mathrm{p}[\mathrm{Kr}+(\mathrm{Y}-\mathrm{V})(\mathrm{L}+1)]$, evolutionary stable strategy should meet that $\mathrm{F}(\mathrm{x})=0$ and $F^{\prime}\left(x^{*}\right)<0$. When $\mathrm{y}>\mathrm{c} / \mathrm{p}[\mathrm{Kr}+(\mathrm{Y}-\mathrm{V})$ $(\mathrm{L}+1)], F^{\prime}(1)<0$, therefore $x^{*}=1$ is steady; When $\mathrm{y}<\mathrm{c} / \mathrm{p}[\mathrm{Kr}+(\mathrm{Y}-\mathrm{V})(\mathrm{L}+1)], F^{\prime}(0)<0$, therefore $x^{*}=0$ is steady. ${ }^{[3]}$

The group evolution of application unit and supervision department could be described by the two differential equations: (1) and (2). From the above, there are five equilibrium points in this replicator dynamics system: E1(0, 0), E2(0,1), E3(1,0), E4(1,1), E5(c/p[ kR+(Y-V)(L+1)],(Y$\mathrm{V}-\mathrm{R}) /(\mathrm{Y}-\mathrm{V}) \mathrm{LP})$. Take the partial of equations (1) and (2) with respect $\mathrm{x}$ and $\mathrm{y}$ individually, getting jacobian matrix: $J=\left[\begin{array}{ll}d f(x) / d x & d f(x) / d y \\ d f(y) / d x & d f(x) / d y\end{array}\right]$

To analyze the stability of equilibrium according to the jacobian and the process as shown in Table 3:

Table 3 Judgement conditions of the equilibrium points

\begin{tabular}{|c|c|c|c|c|c|c|}
\hline & condition & $\begin{array}{l}\text { Number of } \\
\text { equilibrium } \\
\text { point }\end{array}$ & $\begin{array}{l}\text { equilibrium } \\
\text { point }\end{array}$ & $\begin{array}{c}\mathrm{J} \\
\text { determinant notation }\end{array}$ & $\begin{array}{l}\mathrm{J} \text { trace } \\
\text { symbol }\end{array}$ & conclusion \\
\hline $\begin{array}{c}\text { Case } \\
1\end{array}$ & $\begin{array}{c}(\mathrm{Y}-\mathrm{V})(1-\mathrm{LP})-\mathrm{R}>0 \\
\mathrm{PKR}+\mathrm{P}(\mathrm{Y}-\mathrm{V})(\mathrm{L}+1)-\mathrm{C}>0\end{array}$ & 4 & $\begin{array}{l}E_{1} \\
E_{2} \\
E_{3} \\
E_{4}\end{array}$ & $\begin{array}{l}- \\
+ \\
- \\
+\end{array}$ & $\begin{array}{c}\text { Uncertain } \\
+ \\
\text { Uncertain } \\
- \\
\end{array}$ & $\begin{array}{l}\text { saddle point unstable } \\
\text { saddle point } \\
\text { stable }\end{array}$ \\
\hline $\begin{array}{c}\text { Case } \\
2\end{array}$ & $\begin{array}{c}(\mathrm{Y}-\mathrm{V})(1-\mathrm{LP})-\mathrm{R}>0 \\
\mathrm{PKR}+\mathrm{P}(\mathrm{Y}-\mathrm{V})(\mathrm{L}+1)-\mathrm{C}<0\end{array}$ & 4 & $\begin{array}{l}E_{1} \\
E_{2} \\
E_{3} \\
E_{4}\end{array}$ & $\begin{array}{l}- \\
+ \\
+ \\
-\end{array}$ & $\begin{array}{c}\text { Uncertain } \\
+ \\
- \\
\text { Uncertain }\end{array}$ & $\begin{array}{l}\text { saddle point unstable } \\
\text { stable saddle point }\end{array}$ \\
\hline $\begin{array}{c}\text { Case } \\
3\end{array}$ & $\begin{array}{c}(\mathrm{Y}-\mathrm{V})(1-\mathrm{LP})-\mathrm{R}<0 \\
\mathrm{PKR}+\mathrm{P}(\mathrm{Y}-\mathrm{V})(\mathrm{L}+1)-\mathrm{C}>0\end{array}$ & 5 & $\begin{array}{l}E_{1} \\
E_{2} \\
E_{3} \\
E_{4} \\
E_{5} \\
\end{array}$ & $\begin{array}{l}- \\
- \\
- \\
- \\
+\end{array}$ & $\begin{array}{c}\text { Uncertain } \\
\text { Uncertain } \\
\text { Uncertain } \\
\text { Uncertain } \\
0 \\
\end{array}$ & $\begin{array}{c}\text { saddle point saddle point } \\
\text { saddle point saddle point } \\
\text { center }\end{array}$ \\
\hline $\begin{array}{c}\text { Case } \\
4\end{array}$ & $\begin{array}{c}(\mathrm{Y}-\mathrm{V})(1-\mathrm{LP})-\mathrm{R}<0 \\
\mathrm{PKR}+\mathrm{P}(\mathrm{Y}-\mathrm{V})(\mathrm{L}+1)-\mathrm{C}<0\end{array}$ & 4 & $\begin{array}{l}E_{1} \\
E_{2} \\
E_{3} \\
E_{4}\end{array}$ & $\begin{array}{l}- \\
- \\
+ \\
+\end{array}$ & $\begin{array}{c}\text { Uncertain } \\
\text { Uncertain } \\
- \\
+\end{array}$ & $\begin{array}{c}\text { saddle point saddle point } \\
\text { stable } \\
\text { unstable }\end{array}$ \\
\hline
\end{tabular}

According to Table 3, all the balance of game are not evolutionary stable strategy game (ESS). ${ }^{[4]}$ However:

(1) When $\mathrm{PKR}+\mathrm{P}(\mathrm{Y}-\mathrm{V})(\mathrm{L}+1)-\mathrm{C}<0$, i.e. $\mathrm{p}<\mathrm{c} /[\mathrm{kP}+(\mathrm{Y}-\mathrm{V})(\mathrm{L}+1)]$, E3 $(1,0)$ is the stable strategy (ESS).

(2) When $(\mathrm{Y}-\mathrm{V})(1-\mathrm{LP})-\mathrm{R}>0$, $\mathrm{PKR}+\mathrm{P}(\mathrm{Y}-\mathrm{V})(\mathrm{L}+1)-\mathrm{C}>0$, i.e. $\mathrm{c} /[\mathrm{kP}+(\mathrm{Y}-\mathrm{V})(\mathrm{L}+1)]<\mathrm{p}<(\mathrm{Y}-\mathrm{V}-$ $\mathrm{R}) /(\mathrm{Y}-\mathrm{V}) \mathrm{L}, \mathrm{E} 4(1,1)$ is stable strategy $(\mathrm{ESS})$.

\section{Conclusion and suggestion}

(1) It is a process of dynamic game for scientific research project supervision department and the scientific research project application unit's strategy selection. In view of above-mentioned analysis, the successful probability of rent seeking audit $\mathrm{P}$, audit cost $\mathrm{C}$ and the penalties $\mathrm{K}$, $\mathrm{L}$ will influence the strategy selection of supervision department, application unit and approval unit. Therefore, relevant departments for rent-seeking governance should consider the influences of these factors. ${ }^{[5]}$

(2) In the situation of small successful probability of rent-seeking inspection, big inspect cost and small penalty, i.e. $\mathrm{p}<\mathrm{c} /[\mathrm{kP}+(\mathrm{Y}-\mathrm{V})(\mathrm{L}+1)]$ is valid, after many times of game, the supervision department would eventually select not to inspect the rent-seeking, and the application unit would select rent-seeking.

(3) In the situation of big successful probability of rent-seeking inspection, small inspect cost and strict punishment to approval unit for rent-seeking while small penalty to application unit, i.e. c / $[\mathrm{kP}+(\mathrm{Y}-\mathrm{V})(\mathrm{L}+1)]<\mathrm{p}<(\mathrm{Y}-\mathrm{V}-\mathrm{R}) /(\mathrm{Y}-\mathrm{V}) \mathrm{L}$ is valid, after many times of game, the supervision department would eventually select to inspect the rent-seeking, and the application unit would select rent-seeking strategy. 


\section{Acknowledgments}

Thanks for the special fund project (2015jbwy012) of the fundamental research funds for the central universities, the national natural science fund project (71273123) and the central government joint project (B13H100050) of university in Beijing supported by Beijing government.

\section{References}

[1] Wang Chuhong. Discussing on the manifestations, damages and characteristics of the phenomena of rent -seeking in scientific research field. Science Research Management. Vol.25 No.3 May.2004, p.131-136.

[2] Xie Shiyu. Evolutionary Game Theory under Bounded Rationality. Journal of Shanghai University of Finance and Economics. Vol.3 No.5 Oct.2001, p. 3-9.

[3] Sun Qingwen, Lu Liu, Yan Guangle, Che Hongan. Asymptotic Stability of Evolutionary Equilibrium under Imperfect Know ledge. Systems Engineering-theory \& Practice. Vol.7 (2003), p.11-16.

[4] Cang Ping, Wu JunMin, Wang Hong. Evolutionary Game Analysis on Rent-Seeking Regulation of Government Procurement in the Tripartite Model. Journal of Nanjing University of Finance and Economics. No.5 2010 p. 78-83.

[5] LI Gaoyang, LIU Mingguang. Evolutionary Game Model and Strategy Analysis about the Collaboration Innovation of Enterprises, Colleges and Institutes. Science and Technology Management Research. No.3 2014, p. 197-203. 